\title{
THE «COMPETENCE» CONCEPT IN THE EDUCATIONAL SYSTEM OF EUROPEAN COUNTRIES WITHIN A COMPETENCE-ORIENTED APPROACH
}

\section{Yevheniia Spyrydonova ${ }^{I}$}

${ }^{1}$ Department of Education and Law Management, Central Institute of Postgraduate Education, State Higher Educational Institution "University of Education Management" of National Academy of Pedagogical Sciences of Ukraine, Kyiv, Ukraine Commissions of Humanitarian and Social Disciplines, Separate Structural Division "Dnipro Vocational College of Engineering and Pedagogy" of State Higher Educational Institution "Ukrainian State Chemical and Technological University", Kamianske, Ukraine E-mai: jenya.spiridonova@gmail.com

ORCID: https://orcid.org/0000-0002-6080-4700

A RT ICLE INF O
Article history:
Received date 12.10 .2021
Accepted date 25.11 .2021
Published date 30.12 .2021
Section:
Educational Policy \& Reform
D O I

DOI: $10.21303 / 2313-8416.2021 .002238$

KEYWORDS

higher education

competence

professional training of applicants

a list of key educational competencies

legal competence

\section{A BSTRACT}

The object of research is the concept of "competence" in the educational system of different countries.

Investigated problem. Theoretical generalization of the concept of "competence" and the peculiarities of its formation in the process of professional training of applicants for higher education in European countries. Creation of a model of professional training for applicants for education of the first (bachelor's) level.

Main scientific results. The definition of the concepts "competence" and "legal competence", which are most often used in pedagogical research, has been analyzed. The definition of "competence" within the competence-oriented approach is given. The competence-based approach in education is understood as training not just a specialist with a system of knowledge, but a high-level professional and a comprehensively developed personality. A model for the formation of legal competence of applicants for higher education has been created. Through the introduction of innovative methods into educational processes, the legal thinking of bachelors is developing. Legal competence presupposes a set of knowledge, skills, characteristics acquired by students in the learning process, necessary to perform certain actions in order to solve problems, tasks, situations in accordance with the prescriptions of the rule of law. The formation of a system of knowledge, abilities, skills, methods of activity in students in the learning process are significant. This requires both their psychological "restructuring" and the improvement of curricula and educational technologies. The traditional teaching of lectures and the conduct of seminars should be complemented by elective courses and special courses.

The area of practical implementation of the research results. Formation of competencies in the process of professional training of applicants for higher education of the first (bachelor's) level in order to achieve programmatic learning outcomes, apply the acquired knowledge in future professional activities and everyday life.

Innovative technological product. Creation of a training model for applicants for higher education based on a competence-oriented approach.

Application area of an innovative technological product. Introduction of the educational model into the process of professional training of applicants for higher education of the first (bachelor's) level in order to promote the creation and strengthening of legal culture and creativity of students.

(c) The Author(s) 2021. This is an open access article under the Creative Commons CC BY license

\section{Introduction}

One of the components of higher education reforms is the transition to competence-based learning. At the end of the $20^{\text {th }}$ century, a tendency emerged in European education to define the outcome of education in terms of competencies. As the main result of education, a set of key competencies in the intellectual, civil, communication, information and other industries is considered. The geopolitical orientation of the modern civilizational process is determined by its globalization, the growing importance of the humanitarian sphere, high information technologies, post-industrial principles of social development, the increasing role of intellectual capital and management, social and humanitarian factors of economic progress, and the prioritization of basic ones. 
One of the most important strategic tasks of modernizing the higher education system is to ensure the quality of training specialists at the level of international requirements. The post-industrial era with its active development of science, technological revolution, innovations has put forward new requirements for education. The excess of scholastic irrelevant knowledge, the lag of education behind the needs in practice slowed down the transition to a new system of values: individualization of work, an increase in the importance of personal abilities, a willingness to take a creative approach to a particular job, and an increase in the social responsibility of workers for the results of their work. In the new historical conditions, a university graduate must be ready for professional mobility and lifelong learning. Against this background, the need arose for a new educational model.

The formulation of conceptual approaches to the study of the phenomenon of "European dimension of the quality of higher education" requires, first of all, a terminological analysis of its key components. In carrying out such an analysis, let's use several groups of sources:

1) thematic glossaries developed by experts of the Bologna Process;

2) analytical reports of the institutes that provide organizational support and scientific support for the quality assurance in higher education processes in the framework of the Bologna process;

3) scientific research of specialists on the problem under study, in particular, those that were the basis of the first and second groups of sources.

\section{1. The object of research}

The object of research is the concept of "competence" in the educational system of different countries.

Let's note that the subject of consideration will be three interconnected families of concepts, united by the concept of "education", in the first of which the key concept is "higher education", in the second - "European education", in the third - "quality of education". So, the first group of concepts includes: "higher education", "internationalization of higher education", "internationalization of the educational space". In the context of the analysis of the second family of concepts, the subject of consideration will be the following: "European dimension of education", "European dimension of higher education", "European higher education area". The third includes the following components: "quality of higher education", "quality assurance in higher education", "quality assurance in the European Higher Education Area", "European dimension of the quality of higher education". Since a significant part of the above concepts contain signs of two families at once, the logic of their consideration cannot be linear, it is rather concentric in nature, when more complex concepts combine simple ones, forming a new semantic concept. Let's start the implementation of the outlined action plan for terminological analysis with the most general concept - higher education. A terminological analysis of the materials presented in international and national thematic glossaries, other reference books on higher education and its quality allows to assert that formal features of higher education are essential in the context of our research, first of all, its result (acquired academic degree) and the recognition of such the result within the EHEA (compliance with the Framework of Qualifications in the EHEA) and in the world as a whole (compliance with the UNESCO educational level classifier) $[1,2]$.

In this context, let's consider it appropriate to take as a basis the definition presented in the reference book "National Educational Glossary: Higher Education", in which it is stated that higher education is formal education provided at the higher $\left(5^{\text {th }}\right.$ and $\left.6^{\text {th }}\right)$ educational levels according to the International standard classification of education in universities, other institutions of higher education and corresponds to 5-8 levels of the European qualifications framework for lifelong learning. "

\section{2. Problem description}

The main task of society is and will always be to provide quality education to our descendants. The activities of mankind are inextricably linked with a large number of electrical, mechanical and electronic devices. Nowadays, the issue of the formation of legal competence of bachelors is relevant, therefore, the article provides a theoretical generalization of the concept of "competence" and the peculiarities of the formation in the process of professional training of applicants for higher education in European countries. Creation of a model for the formation of legal competence of applicants for higher education 


\section{3. Probable solutions to the problem}

Ensuring the quality of education in the formation of the European education zone is one of the main conditions for trust, mobility, student motivation, compatibility and attractiveness of European higher education.

The development objective of the "European Dimension of Higher Education" was formulated in the founding document of the Bologna Process - the Bologna Declaration (1999). The Declaration notes that the development perspective of Europe "is based and strengthened on its intellectual, cultural, social and scientific and technological dimensions" [3]. The Bologna Declaration identified the development of curricula, inter-institutional cooperation, mobility schemes, joint study programs, practical training and research as ways of shaping the European dimension of higher education. The document also declared the tasks of "promoting European cooperation in quality assurance in terms of developing criteria and methodology" [3]. Support for the formation of the European dimension of higher education was also confirmed in the documents of subsequent BFUG summits, that is, in 33 declarations adopted in Prague [4], Berlin [5], Bergen [6]. Finally, in Yerevan [7], the completion of the formation of the European dimension of the quality of higher education was announced, which became the subject of research.

In Europe, historically, an "English" model of the quality of education [8] was formed, based on the internal self-assessment of the academic community, and a "French" model based on an external assessment of the HEI in terms of its responsibility to society. In Europe, there is still no unified system of institutional assessment of the activities of educational institutions, similar to the accreditation system in the United States. However, each country has its own approaches to ensuring and assessing the quality of higher education.

The European Network for Quality Assurance in Higher Education (ENQA) [9] was established in 2000. The basis of its creation was the pilot project "European Pilot Project for the Assessment of the Quality of Higher Education" (1994-1995), materials of the Recommendations of the European Commission (98/561/EC of September 24, 1998) on European cooperation on quality assurance in higher education and the text of the Bologna Declaration in 1999 [10].

By joining the Bologna Process, Ukraine has undertaken to work to bring the quality of national education in line with European standards.

In order to further develop the national education system, ensure the quality of higher education and its integration into the European and world educational community, by order of the Minister of Education and Science of Ukraine No. 612 dated July 13, 2007, the Action Plan for ensuring the quality of higher education in Ukraine and its integration into the European and the world educational community for the period up to 2010 .

On March 4, 2008 in Brussels (Belgium), Ukraine became a full government member of the European Quality Assurance Register (EQAR). This was an important step towards ensuring the European level of quality in higher education.

The aim of research is to theoretically generalize the concept of "competence", which is most often used in the system of competence-oriented education and to create a model for the formation of legal competence of applicants for higher education.

\section{Materials and methods}

Theoretical and methodological analysis of scientific sources, their systematization, classification, generalization, theoretical modeling in order to study the features of the concept of "competence", the state of the study of the problem.

\section{Results}

A search for a new paradigm of education was carried out in European universities. The Bologna Process became an organizational tool, in the format of which concepts arose that made it possible to get closer to the emergence of a new theory of education, which was in demand by post-industrial society. The experience gained in the implementation of the competence-based approach in the educational systems of the USA, Europe and Ukraine is of particular interest.

In England and the USA, the concept of a competence-based approach to the educational process was formed within the framework of professional educational programs [11]. In the American interpretation, the "competence-based approach" is a "behavioral approach", that is, the orien- 
tation of educational results to the ability to apply them practically after graduation. The learning outcome was planned as a model of a graduate who, in the learning process, will develop his/her personal abilities, professional competencies, understood as the ability and readiness of the graduate to use the knowledge, skills, and abilities acquired in everyday life and practical activities. A feature of the implementation of the competence-based approach in the American experience is the authorship of the corresponding models, which, as a rule, belongs to non-governmental associations that coordinate specialists in the relevant areas of professional activity, which allows to fairly objectively assess the suitability of each applicant for future activities [12].

In the UK, competencies are expressed through subject standards. An integrative model of professional competence was proposed, which includes five groups: cognitive competencies, covering the knowledge gained during training; functional competencies (skills); personal (behavioral) competence; ethical competencies designed to make informed decisions in professional situations; metacompetence as the ability to perceive the remarks of managers and draw the right conclusions [13]. Thus, in assessing the quality of educational outcomes in the UK, there is a broader interpretation of the concept of "competence", covering not only the behavioral characteristics of learning outcomes associated with the specifics of the future professional activity of a graduate of an educational institution, but also the functional characteristics of the quality of knowledge gained and achieved. learning outcomes [14].

The competence-based approach in France is defined as multidimensional, including two areas: personal, focused on the characteristics of the behavior of each applicant for education, and collective, aimed at building a model of competencies necessary for the effective organization of the work of teams and participation in this work of each of the team members [15].

The German education system has adopted a different approach focused on the so-called competence-based actions. The standard typology of competencies is focused on the sphere of future professional activities of graduates of educational institutions. It implies subject, personal and social competence [16].

Thus, in the American educational tradition, the behavioral approach prevails, in the British - the functional, in French and German, the multidimensional and holistic approach to the construction of a competence educational model dominates [17]. The introduction of a competent model for European countries into the national education systems made it possible to bring it to the level of the common European space as a universal tool for the unification of educational systems.

The interpretation of the competence-based approach in Ukraine is based on a concept, the main element of the content of which is objects and knowledge about them. Accordingly, competencies are defined as a method of activity for certain objects [18].

In particular, A. Khutorskyi identifies four elements of the content of education:

1) the experience of cognitive activity - knowledge;

2) experience in the implementation of known methods of activity - in the form of skills, skills to act according to the model and likeness;

3) experience of creative activity - in the form of the ability to acquire a solution and act in a non-standard and problematic situation;

4) experience of the embodiment of emotional-value orientations - in the form of the development of personal orientations [19].

The mastery of these four types of experience, according to the author, will help to form the ability of applicants for education to carry out complex types of actions, called competence.

One of the most important advantages of the competence-based approach is the unity of theoretical knowledge and motivated acquisition of professional knowledge, the formation of a promising environment for self-improvement already at the stage of education. If earlier they were preparing for the successful passing of the exam, now they are aiming at preparing for successful work in the real practice of organizations or individual activities.

At the same time, the question arises about the advisability of interpreting the competence-based approach as a unified model of the educational process. There can be many such constructions. To achieve the quality of education, different areas of work can be used. This includes improving the forms of educational activities, updating the list and content of training courses, changing the nomenclature of specialties. This approach is clear for both students and teachers [20]. The main thing is to form a motivated attitude towards high-quality educational activities. In this 
case, the previously known educational model that is used should only be strengthened by such areas of work that will actively form the competence of graduates.

But the education of socio-political, civic, personal qualities, the formation of a general culture of the individual is impossible without the fundamental theoretical training of a specialist who comes to modern production [21].

The list of key educational competencies within the framework of general education, the structural representation of social experience, as well as the main types of student activities that allow him/her to master social experience, acquire skills in life and practical activity in society, include the following competencies: value-based, general cultural, cognitive, informational, communicative, legal, social and labor, personal self-improvement.

Thus, value-semantic competencies in the field of worldview are associated with the formation of a student's ability to create and be aware of the world around him/her, navigate in it, think over his/her role and purpose, be able to choose target settings, make decisions. These competencies provide a mechanism for self-determination of a young person in teaching and other activities. Their individual educational trajectory and the program of life in general depend on them.

They are complemented by general cultural competencies. The range of issues on which the student should be well aware includes: features of national and world culture, spiritual and moral foundations of human life, culturological foundations of family, social, social traditions, the role of science and religion in life.

General cultural competencies in the domestic and cultural-licensing sphere create the basis for mastering effective ways of organizing free time [22].

Cognitive competencies are a set of qualities of a young person in the field of independent cognitive activity, which includes elements of logical and methodological activity, correlated with real recognizable objects. This includes the knowledge and skills of organizing planning, analysis, self-assessment of educational and cognitive activities. In relation to the studied objects, the student masters the creative skills of productive activity: acquiring knowledge right here and now, mastering the techniques of action in non-standard situations, heuristic methods for solving problems. Within these competencies, the requirements of the corresponding functional literacy are determined: the ability to distinguish facts from conjectures, the use of probabilistic, statistical and other methods of cognition.

The sphere of information competencies includes the ability to independently search, analyze and select the necessary data, as well as organize, transform, store and transmit it through the media, electronic and information technologies. These competencies provide the skills of the student's activity regarding the information contained in academic disciplines, as well as in the surrounding world [23].

Communicative competencies imply knowledge of the necessary languages, ways of interacting with people around and distant people and events, skills in working in a group, possession of different social roles in a team. The student must be able to introduce himself/herself, write a letter, resume, questionnaire, application, ask a question, lead a discussion [24].

Legal competence presupposes a set of knowledge, skills, characteristics acquired by students in the learning process, necessary to perform certain actions in order to solve problems, tasks, situations in accordance with the prescriptions of the rule of law.

Social and labor competencies mean the possession of knowledge and experience in the field of general activity (playing the role of a citizen, choice, representative), in the social and labor sphere (client's rights), in the production of products and services in the field of health care, economics and law, in the field of professional self-government. For example, the ability to analyze the situation, act in accordance with personal and general benefit, possesses the ethics of labor and civil relations. In the learning process, the student masters the minimum sciences of social activity and functional literacy necessary for life in modern life. The competence of personal self-improvement of management based on mastering the methods of physical, spiritual and intellectual self-development, the formation of psychological literacy, a culture of thinking and behavior. These competencies include tasks about their own health, internal ecological culture, a set of qualities associated with the basics of life safety. The formation of such a set of interrelated personality traits in students in the learning process (knowledge, abilities, skills, methods of activity) are significant. This requires both their psychological "restructuring" and the improvement of curricula and edu- 
cational technologies. The traditional teaching of lectures and the conduct of seminars should be complemented by elective courses and special courses.

On the basis of the conducted research and generalization of the definition of "competence", a model for the formation of legal competence of bachelors has been built, containing several blocks:

- I - theoretical, containing the following components - value, cognitive, constructive;

- II - meaningful, containing the following components - methodological approaches, principles, mechanisms and organizational and pedagogical conditions;

- III - educational and technological, contains the following components - forms, methods, stages of activity.

- IV - productive and evaluative, demonstrating the criteria, indicators and levels of formation of the legal competence of bachelors (Fig. 1).

The purpose of the professional training of applicants for education in the process of studying in college, which is reflected in the theoretical block of the model, is to form their integral legal competence, which is ensured by solving the problems:

1) formation and development of the value component, the result of which is the social identity of future professionals;

2) formation and development of the cognitive component, the result of which is social awareness;

3) formation and development of a constructive component, the result of which is the socially competent behavior of future specialists.

The principles of managing the formation of the legal competence of bachelors, presented in the content block of the structural model, are defined: general scientific: purposefulness, consistency and systematicity of molding influences; activity, consciousness; taking into account the age and individual characteristics of applicants for education; the optimal ratio of general, group and individual forms of organization of the educational process; - specially scientific: the unity of the formation of all components of legal competence; the orientation of the educational process - the activation of all three layers (levels) of the functioning of legal competence - personal, educational and professional and social; the orientation of the educational process to students gaining their own social experience; priority of active teaching methods; efficiency and optimality of methods and techniques of formation; motivational support; context; flexibility of molding measures. These principles are formulated on the basis of the above-mentioned methodological approaches to understanding the essence of legal competence and the peculiarities of its formation among bachelors. The generalization of the works of domestic and foreign researchers on the problem of the formation of the legal competence of the individual, as well as the methodological provisions and principles described above, allow to determine the basic mechanisms of this process, which in turn determine its organizational and pedagogical conditions.

The mechanisms for managing the formation of legal competence of bachelors, in our opinion, are as follows.

1) strengthening the quality of social and humanitarian education, the implementation of the right of students to choose various courses related to current social issues, as well as the introduction of an interdisciplinary approach, end-to-end management of the formation of legal competence of bachelors of technical specialties, which should be the task of all academic disciplines and practices;

2) accumulation of individual social experience by students, which can occur in different real and simulated social situations.

In the process of vocational training, such practical teaching methods should be implemented, which make it possible to simulate various social situations. These methods include: trainings, interactive seminars, game methods (role-playing and business games, organizational-active games, etc.), the method of practical situations, professional studios, master classes by specialists and experts, computer simulations, development and participation in social projects

3) strengthening the activities of student self-government bodies, participation in their decision-making on the activities of the university, their vocational training.

4) creation of a special developmental environment in the college, providing an atmosphere of cooperation, partnership of students and teachers, students among themselves, between all subjects of educational interaction (including employers). 
5) strengthening of educational and preventive activities in extracurricular time, activation of self-development processes, self-improvement of students.

6) special training of teachers for the implementation of active methods and forms of work, ensuring the formation and development of the legal competence of applicants for education.

7) intensification of the activities of the socio-psychological service of the college, the implementation by its specialists of systemic legal support for applicants for education; the formation of a positive socio-psychological climate of the student group

8) monitoring the level of formation of legal competence of applicants for education as one of the main indicators of the quality of higher education.

The model for the formation of legal competence was introduced into the educational process of colleges, graduated by specialists at the first (bachelor's) level of higher education. Further study requires the creation of optimal conditions within the college in order to facilitate the disclosure of the potential of future specialists and diagnose the levels of readiness for professional self-realization.

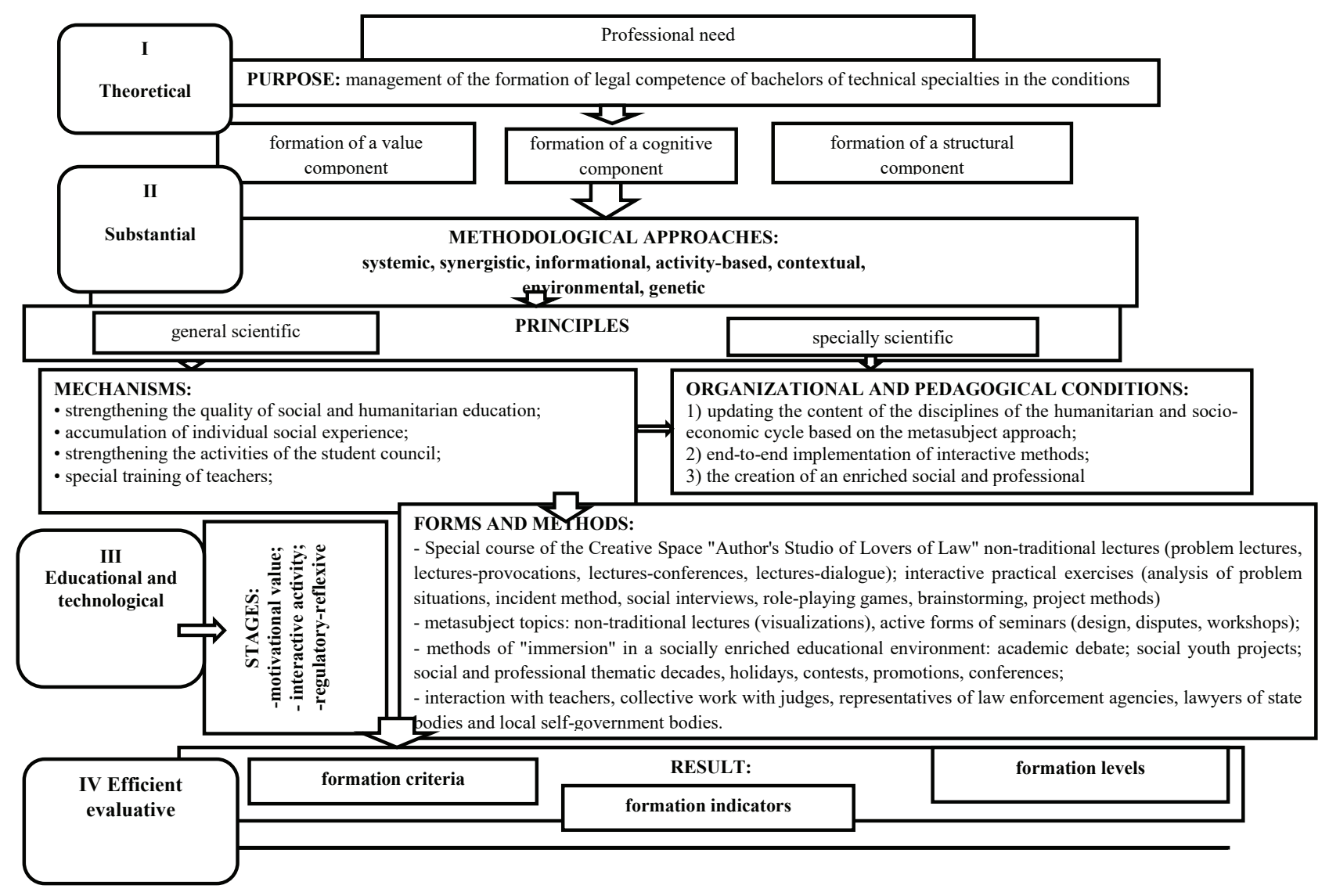

Fig. 1. Structural model of the formation management of legal competence of bachelors

\section{Conclusions}

A model for managing the formation of legal competence of bachelors has been developed and substantiated, aimed at achieving a high level of formation of professional competence of applicants for education. The essence and features of management of the formation of legal competence of bachelors have been determined, where the main goal is to ensure maximum efficiency of the educational and practical process. In addition, the goal of increasing legal awareness is determined, which deepens, expands, details theoretical knowledge and contributes to the development of professional skills. Through the introduction of innovative methods into educational processes, the legal thinking of bachelors is developing, which will allow them to broaden their horizons in their chosen specialty. In the preparation of bachelors, there is a rather powerful educational component, and to improve the quality of training a competitive specialist, let's add a component focused on 
the social and legal characteristics of the labor market. By introducing the legal component into the process of training bachelors, let's form applicants for education of a new higher level with more developed practical skills.

Consequently, the relevance and social significance of the problem under consideration, its insufficient development in Ukrainian pedagogical science, as well as the need to resolve the indicated contradictions determined the choice of the research topic. The competence-based approach in education is understood as training not just a specialist with a system of knowledge, but a high-level professional and a comprehensively developed personality.

\section{References}

[1] Barrows, L. C., Grünberg, L., Parlea, D. (2004). Quality Assurance and Accreditation: A Glossary of Basic Terms and Definitions. Bucharest: UNESCO.

[2] Vlăsceanu, L., Grünberg, L., Parlea, D. (Eds.) (2007). Quality Assurance and Accreditation: A Glossary of Basic Terms and Definitions. Bucharest: UNESCO-CEPES. Available at: https:/www.observatoriorh.org/sites/default/files/webfiles/fulltext/ unesco_cepes_qual_assur_acred.pdf

[3] The European Higher Education Area (1999). Available at: https://www.study.eu/article/the-european-higher-education-area-ehea

[4] Towards the European Higher Education Area (2001). Available at: http://www.encore-edu.org/ENCoRE-documents/prague.pdf

[5] Realising the European Higher Education Area (2003). Available at: http://www.ehea.info/Upload/document/ministerial_declarations/2003_Berlin_Communique_English_577284.pdf

[6] The European Higher Education Area - Achieving the Goals: Communiqué of the Conference of European Ministers Responsible for Higher Education (2005). Bergen. Available at: https://www.eurashe.eu/library/bologna_2005_bergen-communique-pdf/

[7] Yerevan Communiqué (2015). Available at: https:/www.mab.hu/wp-content/uploads/Yerevan_Communique.pdf

[8] Systema zovnishnoi otsinky yakosti vyshchoi osvity v Anhlii (2012). Available at: http://euroosvita.net/?category=17\&id=1611

[9] ENQA. Available at: http://www.enqa.eu/

[10] Glossary of the European Higher Education Area. Available at: https://national-policies.eacea.ec.europa.eu/youthwiki/glossary

[11] Glossary of Education terms (2006). OECD. Available at: https://www.oecd.org/education/skills-beyond-school/33692376.pdf

[12] Glossary on the Bologna process. English-German-Russian (2006). Beiträge zur Hochschulpolitik 7. Conference. Bonn, 196.

[13] De Micheo, R. L., Duclos, V. (2014). The challenges of QA of CBHE: European QA Agencies. Cross-border Higher Education (QACHE) Project Experts' Forum. London: BPP University London.

[14] De Wit, H. (2010). Internationalisation of Higher Education in Europe and its Assessment, Trends and Issues. NVAO Nederlands-Vlaamse Accreditatieorganisatie. Brussels: Education, Audiovisual \& Culture Executive Agency. European Commission, 28.

[15] Rethinking Education: Investing in skills for better socio-economic outcomes (2012). Communication from the Commission to the European Parliament, the Council, the European Economic and Social Committee and the Committee of the Regions. Strasbourg: EC, 669 final.

[16] The European Higher Education Area-Achieving the Goals (2005). Bergen. Available at: http://www.ehea.info/Upload/document/ministerial_declarations/2005_Bergen_Communique_english_580520.pdf

[17] Opening up Education: Innovative teaching and learning for all through new Technologies and Open Educational Resources (2013). Communication from the Commission to the European Parliament, the Council, the European Economic and Social Committee and the Committee of the Regions. EC Available at: https://www.cedefop.europa.eu/en/news/opening-education-innovative-teaching-and-learning-all-through-new-technologies

[18] Lohvinova, Ya. (2011). Obgruntuvannia sutnosti kompetentnistnohoho pidkhodu v osviti u pratsiakh ukrainskykh i zarubizhnykh uchenykh. Porivnialno-pedahohichni studii, 3-4, 48-55.

[19] Khutorskoi, A. V. (2002). Kliuchevye kompetentntsii kak komponent lichnostno-orientirovanoi paradigmy obrazovaniia. Uchinenik v obscheobrazovatelnoi shkole. Moscow: IOSO RAO, 135-157.

[20] Kamyshnikova, H. V. (2015). Do pytannia formuvannia pravovoi kompetentnosti studentiv u vyshchii shkoli. Teoretychni pytannia kultury, osvity ta vykhovannia, 51, 167-170.

[21] Palamar, S. (2018). Competence approach as a methodological landmark of modernization of modern education. Educological Discourse, 1-2. 267-278. doi: http://doi.org/10.28925/2312-5829.2018.1-2.77621

[22] Ovsiienko, L. (2017). Competence approach to education: theoretical analysis. Pedagogical process: theory and practice, 2 , $82-87$.

[23] New priorities for European cooperation in education and training (2015). Joint Report of the Council and the Commission on the implementation of the strategic framework for European cooperation in education and training (ET 2020). Brussels: EC, COM 198 (2015) 408 final.

[24] Rzhevska, N. V. (2016). Kryterii ta pokaznyky sformovanosti pravovoi kompetentnosti maibutnikh bakalavriv iz pidpryiemnytstva, torhivli ta birzhovoi diialnosti. Zbirnyk naukovykh prats: Pedahohichni nauky, 3 (LXXIV), 96-99. 